\title{
Study of free radicals (malondialdehyde) in pre-eclampsia and eclampsia in correlation with uric acid and total proteins
}

\author{
R. Kathyaini ${ }^{1}$, T. Aruna Kumari ${ }^{2, *}$ \\ ${ }^{\mathbf{1}}$ Associate Professor, ${ }^{\mathbf{2}}$ Assistant Professor, Dept. of Biochemistry, Kakatiya Medical College, Warangal, Telangana, India
}

*Corresponding Author:

Email: docmic175@gmail.com

Received: $5^{\text {th }}$ March, 2018

Accepted: $7^{\text {th }}$ May, 2018

\begin{abstract}
Introduction: Oxidative stress is a normal phenomenon in normotensive pregnancy; however, in preeclampsia, oxidative stress is exaggerated may result in a greater potential for endothelial oxidative damage. It has been reported that higher MDA (Malondialdehyde) /total antioxidant capacity (TAC) ratio is indicative of oxidative stress in women with pre-eclampsia.

Materials and Methods: Prospective study was done for duration of 2 years i.e, from January 2015 to December 2017 in the department of Biochemistry at Kakatiya Medical College, Hanmakonda, CKM hospital Warangal. A total number of 60 pregnant women were included in the study. Among these, 20 pregnant women were clinically diagnosed as pre-eclampsia and 20 are eclamptic cases and the remaining 20 were selected as control group and are normotensive antenatal women who are also in third trimester of pregnancy.

Results: The mean MDA, serum uric acid, $24 \mathrm{hr}$ urinary protein were higher in pre-eclampsia and eclampsia compared to controls.

Conclusion: Increased lipid peroxidation products levels clearly shows that oxidation stress is more in pre-eclampsia and eclampsia than in control subjects and it plays a significant role in etiopathogensis of PIH. Serum uric acid levels are significantly higher in cases than in controls and by estimating the uric acid levels we can assess the severity of the disease and we can avoid further progress of the disease process by early detection and prompt treatment. Total serum protein levels are drastically reduced in pre-eclampsia and eclampsia cases compared to controls.
\end{abstract}

Keywords: MDA, Serum uric acid, Proteins, Eclampsia, Pre-eclampsia.

\section{Introduction}

Pre-eclampsia, a syndrome peculiar to pregnancy characterized clinically by hypertension and proteinuria. ${ }^{1}$ In India the incidence of preeclampsia is reported to be $8-10$ per cent of the pregnancies. ${ }^{2}$ Pregnancy-induced hypertension or preeclampsia (diastolic blood pressure $>90 \mathrm{~mm} \mathrm{Hg}$ ) occurring after 20 weeks of gestation with proteinuria (either $\geq 300 \mathrm{mg}$ protein per day or an urinary protein/ creatinine ratio $\geq 30 \mathrm{mg} / \mathrm{mmol})^{3}$

Hypertensive disorders are the most common medical complications of pregnancy, with a reported incidence ranging from 5-10\%. ${ }^{4}$ Hypertension in pregnancy affects mostly after twentieth week of gestation and frequent occurrences are seen near term. This contributes significantly to the cause of maternal and perinatal mortality and morbidity. ${ }^{5-7}$

Oxidative stress is a normal phenomenon in normotensive pregnancy; however, in pre-eclampsia, oxidative stress is exaggerated may result in a greater potential for endothelial oxidative damage. ${ }^{8,9}$ It has been reported that higher MDA/ total antioxidant capacity (TAC) ratio is indicative of oxidative stress in women with pre-eclampsia. ${ }^{9}$

It has been suggested that uncontrolled lipid peroxidation may play a role in the etiology of the PIH. Elevated lipid peroxidation markers like urine (the isoprostane $8, \quad 12$-epi-iPF2 $\alpha$-VI) or plasma (8epiprostaglandin F2 $\alpha$ and MDA) are the markers of oxidative stress. ${ }^{10}$ Recent reports suggest that free radical induced endothelial cell injury might be an etiologic factor. ${ }^{11}$

This study was done to estimate certain biochemical parameters like serum free radicals levels, serum uric acid levels, serum total proteins, and 24 hours urinary proteins in pregnancy induced hypertensive patients. To assess the antepartum, severity and complication of preeclampsia/eclampsia in comparison with normotensive pregnant women by analyzing biochemical parameters to have early detection and better management of toxemia of pregnancy to avoid maternal and fetal mortality and morbidity

\section{Materials and Methods}

The Prospective study was done in the department of Biochemistry in collaboration with department of Obstetrics \& Gynaecology at Kakatiya Medical College, Hanmakonda CKM hospital, Warangal over a period of 2 years i.e, from January 2015 to December 2017. Institute's Ethical committee approval was obtained. The pregnant women were selected randomly. A total of 60 pregnant women were included in the study. Among these, 20 pregnant women were clinically diagnosed as pre-eclampsia and 20 eclamptic cases. All the 40 antenatal women were in $3^{\text {rd }}$ trimester of pregnancy and were admitted in Government maternity hospital. The remaining 20 were selected as 
control group and were normotensive antenatal women who were also in third trimester of pregnancy.

The data of various biochemical parameters is compared between the two groups and students " $\mathrm{t}$ " test was used as statistical method.

\section{Inclusion Criteria}

1. Cases of pre-eclampsia and eclampsia primi patients in the age group of 18 to 30 years and with gestation age more than 20 weeks.

2. Controls of normotensive primi pregnant women in the age group of 18 to 30 years and more than 20 weeks of gestation

\section{Exclusion Criteria}

1. Elderly primi gravida subjects,

2. gestational diabetes,

3. chronic hypertension

4. multiple gestation

5. cardiovascular disease

6. renal disease

7. liver disease

8. endocrine disorders

9. chronic infections

Sample Collection: Blood samples were obtained by venous puncture from the study group immediately after admission and before the commencement of treatment.

Serum was separated after one hour centrifugation and clear serum is transferred to separate aliquots and analysis was done on the same day. Urine samples also collected to assess the 24 hours total urinary proteins.

$5 \mathrm{ml}$ of venous blood samples were collected, the serum was separated and analysed for Malondialdehyde (MDA), a lipid peroxidation product, by thiobarbituric acid reactive substances (TBARS) method and serum uric acid by automated Chemistry Analyser [HUMASTAR 300 (Human Gm BH Germany)] using available commercial kit.

Principle: Malondialdehyde (MDA), a reactive aldehyde is a product of lipid peroxidation. It reacts with thiobarbituric acid (TBA) to form pink colored complex of TBA-MDA adduct and this color is measured at $532 \mathrm{~nm}$. The formation of the MDA-TBA adduct is initiated by a nucleophilic attack involving carbon-5 of TBA onto carbon- 1 of MDA, followed by dehydration and a similar reaction of the intermediate MDA-TBA adduct with a second molecule of TBA.

Reagents: TBA $(0.67 \% \mathrm{w} / \mathrm{v})$ was prepared by dissolving $335 \mathrm{mg}$ TBA in $50 \mathrm{ml}$ of water. TCA $(40 \% \mathrm{w} / \mathrm{v})$ was prepared by dissolving $20 \mathrm{~g}$ TCA in 50 $\mathrm{ml}$ of water.

Procedure: One $\mathrm{ml}$ of serum was mixed with each $1 \mathrm{ml}$ of TCA and TBA. For blank, $1 \mathrm{ml}$ of distilled water was mixed with $1 \mathrm{ml}$ of TCA and TBA. Both the test tubes were kept in boiling water bath and cooled with ice-cold water and centrifuged at $3000 \mathrm{rpm}$ for 10 minutes. The upper clear supernatant fluid was transferred to a cuvette and the absorbance was measured at $530 \mathrm{~nm}$ with a spectrophotometer after adjusting to zero with blank.

Calculation: The MDA level (nmol/l) of serum was calculated based on the molar absorption coefficient of MDA. The molar 5 absorption coefficient for $1 \mathrm{~mol} / \mathrm{L}$ of MDA is $1.56 \times 10$.

\section{Results}

Table 1: Mean and standard deviation of various biochemical parameters in controls and total cases (preeclampsia \& eclampsia)

\begin{tabular}{|l|c|c|c|c|c|c|}
\hline S. No & $\begin{array}{c}\text { Biochemical } \\
\text { Parameters }\end{array}$ & $\begin{array}{c}\text { Mean \& SD } \\
\text { of Controls }\end{array}$ & $\begin{array}{c}\text { Mean \& SD } \\
\text { of Cases }\end{array}$ & $\begin{array}{c}\mathbf{t} \\
\text { value }\end{array}$ & $\begin{array}{c}\text { P } \\
\text { value }\end{array}$ & Remarks \\
\hline 1 & MDA & $1.6 \pm 0.68$ & $5.11 \pm 1.78$ & 9.5 & $<0.001$ & Significant \\
\hline 2 & Serum Uric Acid & $3.5 \pm 0.74$ & $7.2 \pm 1.61$ & 9.0 & $<0.001$ & Significant \\
\hline 3 & Total Serum Proteins & $5.8 \pm 0.74$ & $4.68 \pm 0.73$ & 4.86 & $<0.01$ & Significant \\
\hline 4 & 24hr Urine Proteins & $5.8 \pm 0.70$ & $879.31 \pm 518.27$ & 7.45 & $<0.001$ & Significant \\
\hline
\end{tabular}

Table 2: Mean and standard deviation of various biochemical parameters in preeclampsia \& eclampsia

\begin{tabular}{|l|c|c|c|c|c|}
\hline S. No & $\begin{array}{c}\text { Biochemical } \\
\text { Parameters }\end{array}$ & $\begin{array}{c}\text { Mean \& SD of } \\
\text { Preeclampsia }\end{array}$ & $\begin{array}{c}\text { Mean \& SD of } \\
\text { eclampsia }\end{array}$ & $\begin{array}{c}\mathbf{t} \\
\text { value }\end{array}$ & $\begin{array}{c}\mathbf{P} \\
\text { value }\end{array}$ \\
\hline 1 & MDA & $4.16 \pm 1.27$ & $5.82 \pm 1.99$ & 3.19 & 0.05 \\
\hline 2 & Serum Uric Acid & $7.0 \pm 1.58$ & $7.85 \pm 1.86$ & 1.3 & $\begin{array}{c}\text { Not } \\
\text { significant }\end{array}$ \\
\hline 3 & $\begin{array}{c}\text { Total Serum } \\
\text { Proteins }\end{array}$ & $5.03 \pm 0.9$ & $4.22 \pm 0.77$ & 3.1 & 0.05 \\
\hline 4 & $24 \mathrm{hr}$ Urine Proteins & $754.1 \pm 391.82$ & $1038.45 \pm 558.41$ & 1.86 & $\begin{array}{c}\text { Not } \\
\text { significant }\end{array}$ \\
\hline
\end{tabular}

The mean MDA level in the study group of total 40 cases (preeclampsia and eclampsia) is $5.11 \pm 1.78$ and the control group was 1.6 \pm 0.68. The difference between the means of the two groups was statistically 
significant $(\mathrm{P}<0.001)$. So, we can conclude that there is increase in the oxidative stress in preeclampsia and eclampsia than in controls and we can also compare the mean MDA levels in preeclampsia $4.26 \pm 1.27$, with eclampsia cases that is $5.82+1.99$. So, the oxidative stress is still high in eclampsia cases than preeclampsia according to our study.

The mean serum uric acid level in the study group was $7.2+1.61$ and in the control group was $3.5 \pm 0.74$. The difference between means of two groups was statistically significant $(\mathrm{P}<0.001)$. The mean in preeclampsia cases is $7.0 \pm 1.58$ and mean in eclampsia cases is $7.85 \pm 1.86$.

The mean 24 hour urinary protein in study group $876.31+518.27$ and in control group is $8.55 \pm 43.74$. The difference between the means of two groups was statistically significant $(\mathrm{P}<0.001)$. The mean in preeclampsia cases is $754.1+392.82$ and mean in eclampsia cases is $1038.45 \pm 558.41$.

\section{Discussion}

A total of 20 controls have been studied. All the subjects were normotensive and healthy pregnant women and in $3^{\text {rd }}$ trimester of pregnancy. We found that serum MDA levels, uric acid and total proteins (including 24 hour urinary proteins) in all the control individuals were with in normal limits.

A total number of 20 cases of preeclampsia and 20 cases of eclampsia also in $3^{\text {rd }}$ trimester have been studied. All preeclampsia subjects show classical triad of hypertension, proteinuria and edema.

All the subjects showed an increased levels in all above investigations when compared with control subjects.

The mean MDA level in the study group of total 40 cases (preeclampsia and eclampsia) is $5.11 \pm 1.78$ and the control group was $1.6 \pm 0.68$.The difference between the means of the two groups was statistically significant $(\mathrm{P}<0.001)$.So, We can conclude that there is increase in the oxidative stress in preeclampsia and eclampsia than in controls and we can also compare the mean MDA levels in preeclampsia $4.26 \pm 1.27$, with eclampsia cases that is $5.82 \pm 1.99$ so, the oxidative stress is still high in eclampsia cases than preeclampsia according to our study.

The mean serum uric acid level in the study group was $7.2+1.61$ and in the control group was $3.5 \pm$ 0.74. The difference between means of two groups was statistically significant $(\mathrm{P}<0.001)$.The mean in preeclampsia cases is $7.0 \pm 1.58$ and mean in eclampsia cases is $7.85+1.86$. All the preeclampsia and eclampsia cases are having hyperuricemia.

Uric acid is probably the most important investigation for assesing the severity of pre- eclampsia of all the investigations carried out. It has generally been found to be useful when differentiating the preeclampsia from chronic hypertension, in the latter uric acid level is usually with- in normal range. It is also useful prognostically i.e, the higher is the level of urate the greater is the perinatal mortlity. ${ }^{12}$

A raised urate in the maternal blood results from tissue ischemia and reduced renal clearance, urate is actively secreted by distal convoluted tubules. Damage to distal convoluted tubules in preeclampsia results in decreased urate secretion which results in its increase in the circulation.

Mainly uric acid levels were estimated to indicate the degree of severity of toxemia of pregnancy. A correlation between high serum uric acid, with the severity of disease and perinatal mortality has been suggested by several authors. ${ }^{12}$ An increase in uric acid is a fore runner for proteinuria.

All the preeclampsia and eclampsia patients showed significant proteinuria more than $300 \mathrm{mg} / 24$ hours.

The mean 24 hour urinary protein in study group $876.31+518.27$ and in control group is $8.55 \pm 43.74$. The difference between the means of two groups was statistically significant $(\mathrm{P}<0.001)$. The mean in preeclampsia cases is $754.1+392.82$ and mean in eclampsia cases is $1038.45+558.41$.

The definition o pre-eclampsia can be made if the pregnant women excretes more than $300 \mathrm{mg}$ of protein in $24 \mathrm{hrs}$ urine. These women were at a significantly increased risk of poor perinatal outcome.

Glomerular endotheliosis causes increased leakage of protein in urine. The amount of leakage of protein results in hypoproteinaemia and hypoalbuminemia. According to this study, the mean total serum proteins in control group is $5.8 \pm 0.74$ and in total cases $4.68 \pm$ 0.73 . The difference between the means of two groups was significant $(\mathrm{P}<0.001)$. The mean in pre-eclampsia cases $5.03+0.9$ and the mean in eclampsia cases is $4.22 \pm 0.77$. Hypoprotenemia alter intravascular oncotic pressure and causes the patients to suffer from generalised edema.

Awareness, early detection, effective antenatal services, prompt and proper management will definitely decreases the maternal mortality, morbidity and also perinatal mortality.

In Shikha Saxena et al study Serum MDA level $(\mathrm{mmols} / \mathrm{L})$ in PIH subjects was higher $(1.071 \pm 0.26)$ as compared to the control subjects $(0.42 \pm 0.11)$ and this difference was highly significant $(\mathrm{p}<0.001) .{ }^{13}$

Shikha Saxena et al_study a similar significant difference $(p<0.001)$ was noted for serum uric acid level between the PIH subjects $(6.65 \pm 1.36)$ and the control subjects $(4.72 \pm 0.85)$. The comparison of serum MDA and uric acid levels within control and different PIH sub-groups were found significantly higher $(\mathrm{p}<0.001)$ in PIH I, II and III sub-groups when compared with Group IV (normotensive pregnant women). Similarly MDA level in PIH group III was also found significantly higher $(p<0.001)$ when compared with the other two PIH groups. Uric acid level was also found significantly higher in group III 
when compared with group I $(p<0.01)$ and group II $(p<0.05) .{ }^{13}$ Uric acid level was also found significantly higher in eclamptic women when compared with gestational hypertension $(\mathrm{GH}) \quad(\mathrm{p}<0.01)$ and preeclampsia $(\mathrm{PE})(\mathrm{p}<0.05)$ subjects. ${ }^{13}$

MDA level in eclamptic women was also found significantly higher $(\mathrm{p}<0.001)$ when compared with other two groups.

Other studies conducted by Hubel et al and Freud et al have also shown that lipid peroxides like MDA were significantly elevated in mild and severe PIH. ${ }^{14,15}$ The increased MDA level in PIH is known to be due to increased generation of reactive oxygen species and reduction in anti-oxidants activity. Reactive oxygen species thus produced can cause enhanced lipid per oxidation in PIH which play a significant role in pathophysiology of PIH. ${ }^{16}$

Sharmila Krishnal et al study, the serum MDA (Mean \pm SEM $24.4 \pm 2.38$ vs $7.9 \pm 0.28 \mathrm{nmol} / \mathrm{ml}$ ) and serum uric acid levels $(7.2 \pm 0.25$ vs $3.9 \pm 0.14 \mathrm{mg} / \mathrm{dl}$ were significantly increased in preeclampsia cases compared to that of normotensive pregnant women respectively. They observed a weak positive correlation between Uric acid and MDA in preeclampsia cases. $(\mathrm{r}=$ $0.065, \mathrm{p}<0.734) .{ }^{17}$

Vanitha Gowda MN et al Serum MDA levels were moderately increased in pregnant controls $(1.3 \mathrm{nM} / \mathrm{mL} \pm$ $0.15 \mathrm{p}=\langle 0.001$ for non-pregnant controls vs pregnant controls). In preeclamptic women $(2.52 \mathrm{nM} / \mathrm{mL} \pm$ $0.22)$, the rise in MDA levels was more marked. ${ }^{18}$

\section{Conclusion}

Increased lipid peroxidation products levels clearly shows that oxidation stress is more in pre-eclampsia and eclampsia than in control subjects and it plays a significant role in etiopathogensis of PIH.

Serum uric acid levels are significantly higher on cases than in controls and by estimating the uric acid levels we can assess the severity of the disease and we can avoid further progress of the disease process by early detection and prompt treatment.

Total serum protein levels are drastically reduced in pre-eclampsia and eclampsia cases, compared to controls.

It reflects hyper proteinuria. This test also helpful in assessment of severity of disease, which facilitates initiation of proper treatment and presents development of fatal complications.

The 24 hours urinary protein levels show much higher level i.e, more than $300 \mathrm{mg} / 24 \mathrm{hrs}$ in cases than in controls. This is also good indicator to have awareness about the traid of preeclampsia so that we can guide the patient to have better antenatal care. It can reduce perinatal morbidity and mortality by supplementing iron and protein rich diet.

The comparative study of all the above parameters between the controls and total cases of pre-eclampsia and eclampsia conclude that the parameters are significantly raised in cases than in controls due to various pathological changes in the disease process. So we can conclude that the eclampsia is the more serious and severe form of pre-eclampsia associated with convulsions.

Finally my study shows that free radicals play an important role in the pre-eclampsia and eclampsia. However, further extensive human studies are also needed to confirm the role of oxidative stress.

In this context our results suggest that definite antioxidant supplementation, early diagnosis, prompt treatment, better antenatal services reduce the severity of complications.

\section{Conflict of Interest: None}

\section{Acknowledgement: Nil}

\section{References}

1. Zamorski MA and LEE A. Green LA, NHBPEP Report on High Blood Pressure in Pregnancy: A Summary for Family Physicians. Am Fam Physician. 2001;15(2):263271.

2. Krishna Menon, M.K. and Palaniappan, B. (1994). Hypertensive disorders of pregnancy. In Mudaliar Menon (ed.). Clinical Obstetrics. 9th edn. Orient Longman, Madras, 133-154.

3. Cunnigham FG, Leveno KL, Bloom SL Hauth JC, Gilstrap LC and Wenstrom KD,. Hypertensive disorders in pregnancy. In: Cunnigham FG, Leveno KL, Bloom SL, editors. Williams Obstetrics. 22nd ed. NewYork; McGraw-Hill; 2005:chap 34, 1237.

4. Sibai, B.M. Hypertension in pregnancy. Obstet Gynecol Clin North Am. 1992;19:615.

5. National High Blood Pressure Education Programme Working Group. Report on High Blood Pressure in Pregnancy. Am J Obstet Gynecol. 1990 Nov;163(5 Pt 1):1691-712.

6. JC, Adler S, Burkart JM, Greene T, Hebert LA, Hunsicker LG et al. Blood Pressure Control, Proteinuria, and the Progression of Renal Disease. The Modification of Diet in Renal Disease Study. Ann Intern Med. November 15, 1995;123(10):754-762

7. Luciano E. Mignini, MD, a, b Jose Villar, MD, a Khalid S. Khan, MDb Mapping the theories of preeclampsia: The need for systematic reviews of mechanisms of the disease. Am J of Obste and Gynec. 2006;194:317-321.

8. O.B. Idonije, O. Festus, O. Okhiai and U. Akpamu. A Comparative Study of the Status of Oxidative Stress in Pregnant Nigerian Women. Research Journal of Obstetrics and Gynecology, 2011;4:28-36.

9. Davidge ST, Hubel CA, Brayden RD, Capeless EC, Mclaughlin MK. Sera antioxidant activity in uncomplicated and preeclamptic pregnancies. Obstet Gynecol. 1992;79:897-901.

10. Morris JM, Gopaul NK, Endresen MJR, Knight M, Linton EA, Dhir S, Anggard EE, Redman CWG. Circulating markers of oxidative stress are raised in normal pregnancy and pre-eclampsia. Br J Obstet Gynaecol. 1998;105:1195-1199.

11. Hung TH, Burton GJ. Hypoxia and reoxygenation: a possible mechanism for placental oxidative stress in preeclampsia. Taiwan J Obstet Gynecol. 2006;45(3):189200. 
12. Chappell LC, Seed PT, Briley AL, Kelly FJ, Lee R, Hunt $\mathrm{B}$, et al. Effect of antioxidants on the occurrence of preeclampsia in women at increased risk: a randomised trial. Lancet. 1999;354:810-6.

13. Shikha Saxena, Prem Chandra Srivastava, K.V. Thimmaraju, Biswajit Das, Ayaz K. Mallick, Study of Serum Malondialdehyde and Uric Acid in Pregnancy Induced Hypertension \& Its Medico-Legal Significance. $J$ Indian Acad Forensic Med. January-March 2014;36(1):55-60.

14. Hubel CA, Roberts JM, Taylor RN, Thomas J, Rogers GM and Mc Laughlin ML. Lipid peroxidation in pregnancy: New and Gynecol. 1989;161:1025-34.

15. Freud G and Arvan D. Clinical biochemistry of preeclampsia and related liver disease in pregnancy: A review. Clin Chim Acta. 1990;191:123-52

16. Meera KS, Maitra S, Hemalatha R. Increased level of Lipid peroxidation in preeclamptic pregnancy; a relationship with paraoxanase 1 (PON1) activity. Biomedical Research. 2010;21(4):393-96.
17. Sharmila Krishna, E. Venkata Rao, B. Sowjanya, A. Saseekala, J. N. Naidu. Correlation between malondialdehyde (MDA) and uric acid levels in preeclampsia. Int J Res Med Sci. 2015 Jun; 3(6):14431445.

18. Vanitha Gowda MN, Aroor AR, Krishna L Studies on Oxidative stress in Preeclampsia, Biomedical Research 2010;21(1):71-79.

How to cite this article: Kathyaini R, Kumari TA. Study of free radicals (malondialdehyde) in preeclampsia and eclampsia in correlation with uric acid and total proteins. Int $\mathbf{J}$ Clin Biochem Res. 2018;5(3):453-457. 